\title{
Project Learning Tree-Canada
}

\author{
by
}

A. D. Hall1

\section{Introduction}

The Provincial Forestry Associations and Canadian Forestry Association have all been engaged in resourceeducational activities over the years. Indeed, C.F.A. and its member groups have pioneered in many programs to help young people learn more about the place of forests and other resources in their environment. They introduced such activities as bringing motion pictures to schools, travelling school rooms (railway cars) and portable projection equipment, outdoor education study areas, lecture series in schools, teachers' workshops in conservation, poster contests, etc. A recent development has been the introduction of Project Learning Tree into Canada.

\section{Some Background on Project Learning Tree (P.L.T.)}

The development of Project Learning Tree arose out of a serious problem encountered by resource managers in the United States who were faced with increasing criticism from the general public, many of whom were "illiterate" in terms of real understanding of the importance of the forest resource, its management and its interaction with environmental and people needs. As in Canada, industry and other forest managers tried to meet the situation by expanding their public relations program, but these frequently lacked continuity and, in some cases, credibility. In the schools, teachers were interested in the forest environment but frequently ignored the entire subject because they lacked resources and understanding to give a balanced picture. Furthermore, available educational materials and services did not integrate easily into already overcrowded school curricula.

In recognition of the need for better understanding of resource management by the general public and the difficulties experienced by the educational system in encouraging this, a new approach was taken by the American Forest Institute - the information and education arm of the United States Forest Products Industry. This approach embodied in the "Project Learning Tree" program - involved the development of appropriate educational materials by foresters from government and industry, and by other resource managers, environmentalists and citizen conservation groups working in co-operation with many teams of elementary and secondary school teachers. The P.L.T. teaching manuals that resulted therefore present a full spectrum of positions. Because of teacher input the lesson plans incorporate effective educational strategies and fit within existing school curricula.

The essence of Project Learning Tree is that forestry and resource management are not presented as specific courses per se but are integrated as interesting, relevant, activities which can be used in most of the core subjects from kindergarten through Grade 12. No special time period has to be withdrawn from the school day and the lessons fit directly into studies in social science, mathematics, English, science, music, art, etc. This means students develop understandings about resources throughout their primary and secondary school education. Manuals have been developed for the elementary and secondary school levels. An example of one of the many elementary lessons has students working with a large cross-section of a tree and

\footnotetext{
Executive Director, Canadian Forestry Association

185 Somerset St. W. Ottawa, Ont. K2P 0J2
}

pin-pointing the dates of important events and the birthdates of the parents and in this way absorbing a good perspective on how long it takes trees to grow and something of their life cycle. The secondary manual has some 89 similar lessons such as "Which Should I Buy" in which the classroom is presented with the situation where wood has been abandoned and replaced by materials derived predominantly from non-renewable resources. The research involved leads to better understanding of the trade-off in man-resources choices. It also develops important reporting and other skills.

At both levels, these lesson manuals are essentially outlines or activity guides that show teachers anywhere how to work with resources in their own local areas - not only trees, soils, water and others but also people and industry, government, business and the community. The manuals are not distributed freely to teachers but are given out only after they attend workshops showing their application.

The Program helps students learn where to find information and also encourages resource managers to produce appropriate information and provide input into the educational process, often through direct contact with student projects. The Program can only be introduced with close cooperation and support from the local or regional educational authorities.

Through arrangement with the American Forest Institute, the Program was first introduced into Canada by the Canadian Forestry Association of B.C. which initiated it at school opening in September, 1977. Introduction was preceded by considerable spade work which included submitting the materials for review to the University of British Columbia Faculties of Education and Forestry, the B.C. Institute of Technology Forestry Department, individual teachers and others, and also for field testing by the elementary Science and Curriculum Review Committee of the Ministry of Education. Uniformly positive comment was followed by a workshop to familiarize representatives of forest-related provincial ministries, the major forestry associations, industry and education delegates. Response reinforced the view that the Project Learning Tree lessons would be acceptable and of value in British Columbia. The first teachers' workshop was held in October 1977 and since that time the problem has been one of trying to adequately service and fit everyone in. To December 1979, C.F.A. of B.C. had held 129 workshops with 2,741 participants at the five major regions within the province. They had also supplied during this period some 69,000 background references to students, youth leaders and teachers, and have assigned staff persons to co-ordinate workshops and programs.

\section{In Other Provinces}

The Forestry Associations have taken natural leadership in this program both because of the inter-provincial communication liaison provided through membership in C.F.A. and also because of their long standing close co-operation with education with education authorities. In one region a CIF Section initiated investigation of P.L.T.

In 1980 the program is being fully introduced into New Brunswick by the Canadian Forestry Association of N.B. They have assigned a staff person for the last two years to study and develop their participation and to lay the necessary co-operative groundwork. The staff person has met with her B.C. counterpart as well as attended P.L.T. workshops in the United States. Pilot teacher workshops were held for elementary and secondary school teachers in 
1979. Project Learning Tree will be a major project of the Canadian Forestry Association of New Brunswick in 1980.

In Québec a staff member of the Department of Lands and Forests Education Branch (directed by the former manager of the Québec Forestry Association) visited B.C. two years ago to learn more about P.L.T. Since that time interest in the program has increased and the Québec Forestry Association has been closely involved in assessing potential development. One of the problems in Québec is the necessity of translating manuals into French. It appears that P.L.T. may be adopted by the Québec Forestry Association although a final commitment has not been made at this time.

The Saskatchewan Forestry Association has been looking into the program with the possibility of introducing it to that province. They have had correspondence and discussion with B.C. and New Brunswick. They have met with Saskatchewan Department of Education officials and expect that negotiations and the planning stage will last about one year before a final decision can be made about introducing P.L.T. to Saskatchewan.

In other provinces there is varying interest in P.L.T. and some consideration of its place relative to other outdoor education projects. Some are carefully watching experiences in the regions where the program is established or is being introduced. It is possible for a variety of reasons that not all provinces will find it appropriate or possible to introduce P.L.T. into their school systems.

\section{Generally}

Development of Project Learning Tree involves spade work of at least two years, plus considerable staff time and expense to build up the necessary co-operation and coordination. A large number of volunteers - including foresters - are needed at every stage of the introduction and implementation of the program. Successful support requires significant funding to prepare appropriate material and to run teacher workshops at centres throughout a province. A written agreement has to be signed with the American Forest Institute by the agency sponsoring Project Learning Tree.

The Canadian Forestry Association of British Columbia has developed a special Forestry Education Foundation primarily concerned with providing necessary funds for the development of P.L.T. in that province. By spring of 1980 this fund had reached $\$ 300,000$. Other Provincial Forestry Associations are seeking special financial support and volunteered assistance of services, people, and materials to assess the program or get it underway.

\section{In Conclusion}

Project Learning Tree was developed in the United States and has been introduced into Canada. Educational authorities are finding it helpul as a means of introducing information and principles on resources and their management into primary and secondary school systems. Associated projects and lesson plans are integrated into existing subjects and curricula. The P.L.T. program is currently sponsored in Canada by two Provincial Forestry Associations and is being investigated by others. Successful implementation involves long-term commitment by the sponsoring body. Many members and some Sections of the Canadian Institute of Forestry have worked closely with Forestry Association in this project.

\title{
Eight for the Eighties
}

\author{
M. F. Painter ${ }^{1}$
}

\section{The Critical Decade}

The Canadian Forestry Association has called the 1980's the "Decade of Decision", and it will be worthwhile, as the decade begins, to consider eight challenges confronting foresters and needing some decisive action.

Before outlining these challenges, however, a little background is in order, to show why they are important. Foresters can fall into the trap of not being able to see the wood for the trees as they immerse themselves in the biological details of their profession. In the last few years, though, many foresters have taken a wider view, recognized the importance of the decade and started to get the message abroad.

Three years ago, Les Reed's "Forest Management in Canada" woke a lot of people up to the fact that we were caught with our forests down. Demand in the U.S.A. and Canada could absorb more than we could grow by the end of the century, yet other customers would be clamouring for wood and the needed trees were not in the ground.

In 1977 in Quebec City, thanks to the efforts of Dal Hall, Gerry Burch and Marcel Lortie - to name a few of many -

\footnotetext{
${ }^{1}$ M. F. Painter and Associates, 7088 Angus Drive, Vancouver, B.C. V6P 5J7
}

a national regeneration conference stirred a missionary zeal to "spread the bad news", as Jack Walters put it. It's late. The 1990's will really make it obvious that this effort should have started twenty years ago. Nevertheless, the message is getting across. Jack Munro and his members in the I.W.A. quickly recognized, to their credit, that forestry is too important to leave to foresters alone. The Federal Government has at least made a start in giving forestry a little more of the recognition it deserves. Provincial governments are showing inclinations to throw a little money and talent at the problems. The focus of many conferences - the Financial Post Conference on Canada's forest products which took place last February, and the September Forestry Congress sponsored by the Canadian Pulp and Paper Association, to name two - is being directed to the need to plant more jobs in the bare places in our forests.

The stage is set. But if anyone thinks the forester's job is done they should get last December's "Forestry Chronicle" and read Gordon Baskerville's letter to the editor. Gordon says foresters have been talking about "educating the public" and "convincing the politicians" for 25 years but have developed no plan of specific action for our forests. The real problem, he suggests, is us.

Let's look at the eight challenges which foresters should be meeting with some specific planning. 